\title{
FILOSOFI DAN PENERAPAN KONSEPSI BUNGA PADMA DALAM PERWUJUDAN ARSITEKTUR TRADISIONAL BALI
}

\author{
I Nyoman Widya Paramadhyaksa \\ Fakultas Teknik, Universitas Udayana \\ paramadhyaksa@yahoo.co.jp
}

\begin{abstract}
Abstrak
Padma adalah sebutan bunga teratai merah dalam bahasa Sanskerta. Padma tumbuh secara alami di media lumpur dengan kandungan air yang cukup. Akarnya tumbuh menjalar di media tanah, batangnya terendam di air, sedangkan daunnya yang lebar mengapung di permukaan air. Bunga padma yang sedang mekar berada di atas permukaan air, menengadah, bersih dari noda lumpur, dengan kelopaknya yang merekah sempurna ke segala arah. Karakter fisik padma yang sedemikian rupa ini telah lama melahirkan ilham dijadikannya padma sebagai bunga suci dalam ajaran Hindu dan Buddha. Dalam seni lukis dan seni arca timur, padma juga sering dijadikan lapik atau atribut yang digenggam tokoh dewa-dewi tertentu. Di Bali, padma juga dijadikan sebagai konsepsi dasar wujud bangunan suci dan arah mata angin. Kelopak-kelopak bunga padma yang merekah sempurna sering kali dikaitkan dengan keberadaan delapan arah mata angin utama yang diyakini dijaga oleh para dewata utama pula. Tulisan ini merupakan ringkasan dari suatu kajian yang menerapkan metode hermeneutik tentang filosofi bunga padma dan keterkaitannya dengan konsep arah mata angin utama yang dikenal dalam tatanan arsitektur tradisional Bali. Pada beberapa bagian juga akan dipaparkan gambaran wujud penerapan konsepsi bunga padma tersebut dalam berbagai perwujudan arsitektur tradisional Bali. Hasil akhir penelitian ini menunjukkan bahwa Konsepsi Padma ini telah terejawantahkan dalam tata ruang Pulau Bali, tata mandala pura, seni bangunan suci, dan seni ikonografis arca tradisional Bali.
\end{abstract}

Kata kunci: Padma, delapan arah mata angin, konsepsi, arsitektur tradisional Bali.

\begin{abstract}
Padma refers to red water lily in Sanskrit. Padma grows naturally in the mud media with enough water content. Its roots spread in the soil planting media, the stem is submerged in water, while the leaves float on the water surface. Water lily flower blooms above the surface of the water, looking up, clean from mud, with petals that splitting all directions. Such padma's physical characteristics have brought inspiration so that it becomes a sacred flower in Hinduism and Buddhism. In Eastern art, padma is often used as a pedestal or character attributes of certain gods or goddess. In Bali, padma serves as the basic concept of the sacred structure form and eight directions. The splitting petals of padma are often associated with the presence of the eight cardinal directions guarded by eight major gods. This paper is a summary of the study which applied the methods of philosophical hermeneutics on the philosophy of padma and its relevance to the concept of the main wind direction known in the order of traditional Balinese architecture. In some parts, it is also described the application description of Padma concept various embodiments of the Balinese traditional architecture. The final result of this research shows that Padma concept applied on Bali island masterplan, Hindu temple mandalas, holy buildings and iconographic of traditional Balinese sacred statues.
\end{abstract}


Keywords: Padma, eight directions, concept, Balinese traditional architecture.

\section{Pengantar}

Padma adalah sebutan tanaman bunga teratai merah (lat. Nymphaea rubra) dalam bahasa Sanskerta. Ada tiga jenis teratai lainnya yang juga memiliki nama khusus dalam bahasa Sanskertanya, yaitu teratai putih (Skt. kumuda) (lat. Nymphaea alba); teratai kuning (Skt. nilpala) (lat. Nymphaea mexicana); dan teratai biru (Skt. utpala) (lat. Nymphaea capensis). Tanaman teratai merah memiliki karakteristik selayaknya tanaman teratai pada umumnya yang merupakan sejenis tanaman air tawar itu. Akar dan umbinya tumbuh menjalar di dalam lumpur di bawah air; batangnya tumbuh terendam dalam air; sedangkan daunnya yang lebar mengembang berada di atas permukaan air. Tunas bunga padma yang masih muda akan tumbuh dari umbi tanaman yang berada di media lumpur di dasar kolam atau danau. Tunas bunga ini akan makin membesar dan bertumbuh menaik ke permukaan air. Ketika tunas bunga tersebut sudah mencapai masanya, bunga itu akan mekar, merekah mengembang di atas permukaan air. Bunga padma yang mekar akan terlihat mengembangkan seluruh kelopak mahkota bunganya yang berwarna merah itu. Sari bunganya berada di bagian tengah bunga, sebagai tempat serbuk sari dan kepala putik bunga. Tanaman ini berkembang biak dengan umbi atau biji buah yang tumbuh berkembang dari bunganya.

Tanaman padma dan tanaman teratai lainnya dikenal sebagai tanaman suci dalam pandangan Agama Hindu, Buddha, dan berbagai agama lokal yang tumbuh berkembang di wilayah Asia Timur, Asia Tenggara, Asia Tengah, dan Asia Selatan (Gupte, 1980: 2). Di Mesir, teratai juga dikenal sebagai salah satu tanaman yang disucikan dan banyak dijadikan sebagai motif ragam hias bangunan, lukisan, dan patung (Altman, 2002: 95). Karakter teratai yang tumbuh di tiga jenis media yang berbeda, yaitu tanah (lumpur), air, dan udara menjadi salah satu dasar pertimbangan ditetapkannya tanaman air tawar ini sebagai tanaman yang mampu mewakili karakter tiga tingkatan alam jagat raya yang dikenal dalam filsafat dunia timur, yaitu alam bawah, alam tengah, dan alam atas. Keberadaan tanaman teratai dalam filsafat dan seni klasik Dunia Timur berkembang secara bersamaan dan berdampingan dengan konsepsi tanaman air tawar lainnya, yaitu seroja atau lotus (lat. Nelumbo nucifera). Kedua jenis tanaman air ini juga dikenal memiliki berbagai karakter utama yang memuat nilai filosofis yang tinggi.

Hasil studi pustaka awal yang telah dilakukan menunjukkan bahwa di Bali, istilah bunga padma banyak dikaitkan dan digunakan dalam konsep tata ruang, bidang ilmu arsitektur, dan seni rupa, seperti sebagai konsepsi tata ruang Pulau Bali, konsepsi tata mandala pura, dan konsepsi seni bangunan, dan seni arca. Eksistensi Konsepsi Bunga Padma juga acap kali dikaitkan dengan konsepsi-konsepsi lainnya, seperti konsepsi arah mata angin, Konsepsi Dewata Nawa Sanga, dan Konsepsi Asta Dik Pala. Perwujudan Konsepsi Padma dalam tata ruang, seni bangunan, dan seni arca juga beragam rupanya serta sudah diaplikasikan secara turun temurun di Bali.

\section{Metode Penelitian}

Tulisan ini merupakan ringkasan dari hasil penelitian yang telah dijalankan tentang Konsepsi Bunga Padma dan wujud penerapannya dalam bidang kearsitekturan di Bali. Penelitian ini tergolong sebagai sebuah penelitian kualitatif yang menerapkan metode hermeneutik aliran Heidegger. Metode penelitian ini pada dasarnya menekankan pada upaya penafsiran makna suatu materi penelitian yang diperoleh berdasarkan suatu tahap kajian yang mengorelasikan materi tersebut dengan objek maupun materi lain yang memuat substansi makna yang berkaitan dengannya. Objek-objek lain tersebut berasal dari masa yang sama atau sebelumnya. 
Dalam konteks penelitian ini, materi kajian adalah berupa Konsepsi Padma beserta segala latar filosofis dan pengertian yang termuat di dalamnya. Adapun materi dan objek komparatif yang dikorelasikan dengannya adalah berupa (a) Gambaran tentang Konsepsi Bunga Padma yang tersurat dalam naskah manuskrip tradisional Bali (lontar); (b) gambaran tata ruang tradisional Pulau Bali secara makro; (c) gambaran tata ruang Kota Trowulan; (d) perwujudan bangunan tradisional Bali yang memuat Konsepsi Padma; (e) seni ikonografi tokoh dewa Hindu dan Buddha; (f) seni arca dewata di Bali; dan (g) perwujudan ragam hias bangunan Bali yang memuat Konsepsi Padma.

Hasil kajian diringkas sebagai suatu simpulan akhir penelitian yang disusun melalui penalaran secara deduktif.

\section{Tinjauan Pustaka}

Pada bagian berikut ini dipaparkan tentang beberapa hasil tinjauan pustaka tentang konsepsi-konsepsi yang berkaitan dengan padma.

\section{Konsepsi tentang Padma, Dewata Nawa Sanga, dan Asta Dik Pala}

Dalam lontar kuno terkenal di Bali bertajuk Padma Bhuwana, tersurat sebuah ungkapan simbolik dari seorang tokoh suci bernama Mpu Kuturan yang menggambarkan tingkat kesucian alam Pulau Bali pada masa dahulu. Dalam lontar tersebut tertulis bahwa pada sekitar abad ke-11, tokoh pendeta sakti yang menganut agama Siwa-Buddha tersebut telah memberikan Pulau Bali sebuah julukan mulia yang pada akhirnya dikenal hingga saat ini, yaitu Padma Bhuwana. Istilah Padma Bhuwana tersebut pada dasarnya tersusun dari dua buah kata yang berasal dari bahasa Sanskerta, yaitu padma dan bhuwana. Padma memuat arti sebagai 'bunga teratai merah', sedangkan bhuwana dapat diterjemahkan sebagai kata 'alam' atau 'dunia'. Rangkaian kedua kata Sanskerta tersebut, dalam konteks julukan "Padma Bhuwana", tidak serta merta diartikan dalam bahasa Indonesia sebagai 'dunia teratai merah' atau 'alam teratai merah'. Dalam konteksnya sebagai julukan Pulau Bali, rangkaian istilah itu tentunya menjadi lebih tepat apabila diterjemahkan sebagai 'Pulau Padma' atau 'Pulau Bunga Teratai Merah'. Julukan ini pada intinya mengibaratkan karakter Pulau Bali pada masa lalu sebagai bunga teratai merah yang mengapung di atas air. Kelopak-kelopak bunganya yang berwarna merah merekah menengadah ke atas dan mengembang sempurna ke segala arah mata angin (Wiana, 2004: 69-71).

Pengibaratan Pulau Bali sebagai bunga padma oleh seorang tokoh suci keagamaan masa lalu berulang kembali pada pertengahan abad ke-15. Pada masa itu, seorang tokoh suci dari Jawa lainnya yang bernama Danghyang Nirartha mengandaikan Pulau Bali pada masa itu sebagai bunga padma yang tidak memiliki sari. Perumpamaan yang menggambarkan adanya kekuranglengkapan semacam ini berkaitan dengan tata cara ritual pemujaan dan persembahyangan pada waktu itu yang dinilai masih kurang sempurna. Masyarakat Bali pada masa-masa itu dalam melakukan kegiatan persembahyangan, pendirian bangunan suci, dan aneka aktivitas peribadatan cenderung hanya ditujukan kepada pada tokoh-tokoh dewa manifestasi dari Ida Sanghyang Widhi Wasa/Tuhan Yang Mahaesa. Kegiatan keagamaan yang difokuskan pada Ida Sanghyang Widhi Wasa sendiri relatif belum dijalankan dengan baik. Realita kehidupan di Bali pada masa lalu semacam inilah yang dikiaskan oleh Danghyang Nirartha sebagai gambaran sebentuk bunga padma yang mekar indah merekah akan tetapi tanpa memiliki sari di tengahnya. Dalam perkembangannya, Danghyang Nirartha selanjutnya juga menciptakan sebuah desain bangunan suci Padmasana sebagai bangunan suci utama untuk pemujaan kepada Tuhan Yang Mahaesa (Ida Sanghyang Widhi) yang dikenal di Bali hingga kini. Bangunan ini mengambil ilham dari wujud bunga padma yang sedang mekar sempurna sebagai simbol singgasana Tuhan Yang Mahaesa (Eiseman dan Margaret, 1989: 78). 
Di samping dimaknai sebagai gambaran simbolis Pulau Bali, padma juga banyak berperan dalam perwujudan seni arca, pahat, dan arsitektur di Bali. Dalam seni arca, padma banyak dijadikan motif lapik yang berwujud landasan pijakan kaki atau tempat duduk berbagai tokoh dewa dan dewi. Dalam seni pahat, padma juga banyak mengilhami lahirnya berbagai wujud ornamen dan elemen dekoratif bangunan berlanggam Bali. Dalam pengetahuan arsitektur bangunan suci Hindu Bali, padma juga menjadi landasan konseptual bagi beberapa bangunan suci utama Hindu Bali yang dikenal hingga saat ini, seperti Padmacapah, Padmasari, Padmasana, dan Padmayoni.

Sifat keutamaan bunga padma juga menjadi ilham bagi lahirnya beberapa konsepsi keagamaan lainnya. Dalam konstelasi dewa-dewi Hindu India maupun Nepal dikenal adanya beberapa tokoh dewata yang digambarkan selalu menggeggam atribut berupa setangkai bunga padma, seperti Dewi Laksmi, Dewa Wisnu, dan Dewi Parwati.

\section{Korelasi Konsepsi Padma dan Dewata Nawa Sanga}

Dewata Nawa Sanga yang disebut juga sebagai Nawa Dewata ('sembilan tokoh dewata') merupakan sembilan tokoh dewa yang dipuja sebagai penjaga sembilan arah mata angin dalam ajaran agama Hindu Bali (lihat gambar 1). Kesembilan arah yang dimaksud adalah arah utara, timur laut, timur, tenggara, selatan, barat daya, barat, barat laut, dan tengah atau pusat. Kesembilan tokoh dewa tersebut masing-masing menempati posisi tertentu di salah satu dari sembilan arah yang ada. Tiga dari sembilan tokoh dewa ini, yaitu Brahma, Wisnu, dan Siwa merupakan tokoh-tokoh dewa utama dalam Agama Hindu yang disebut sebagai Tri Murti. Enam tokoh dewata lainnya, yaitu Sambhu, Iswara, Maheswara, Rudra, Mahadewa, dan Sangkara dimaknai pula sebagai enam inkarnasi lain dari Dewa Siwa itu sendiri.

Masing-masing tokoh dewa tersebut juga digambarkan pula memiliki wahana, pasangan (sakti), aksara suci, warna, senjata, dan beberapa atribut khusus lainnya. Di Pulau Bali, kesembilan tokoh dewa ini juga dipuja di beberapa pura utama berstatus Pura Kahyangan Jagat yang disebut juga sebagai Pura Padma Bhuwana atau Pura Padma Astadala ('pura delapan kelopak bunga padma') (lihat gambar 3). Konsepsi pemujaan kesembilan tokoh dewa ini di Bali semacam ini adalah sejalan dengan Konsepsi Padma Bhuwana dan simbolisasi Pulau Bali sebagai bunga padma besar yang sedang mekar mengapung di atas air dengan sebuah sari di tengah-tengah dan delapan helai kelopak mengembang pada delapan arah yang berbeda (Manuaba dan Suparta, 1999: 76). 


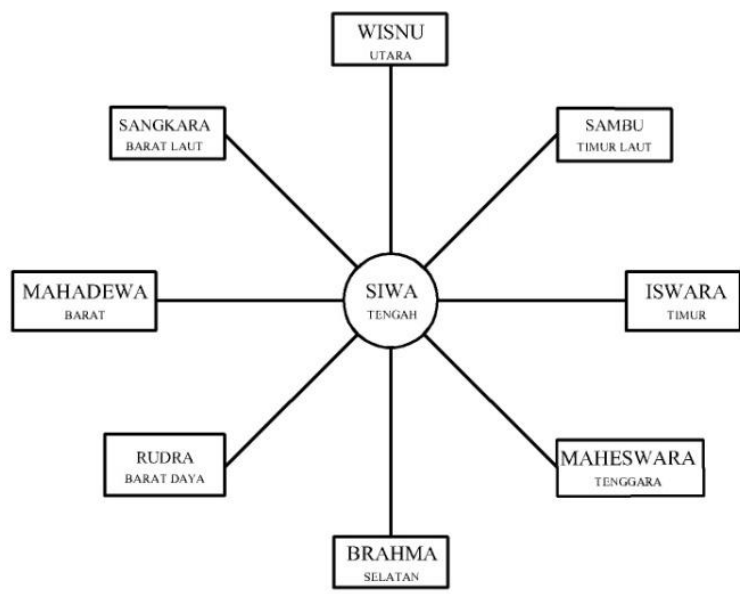

Gambar 1. Konsepsi Dewata Nawa Sanga Sumber: Analisis, 2016

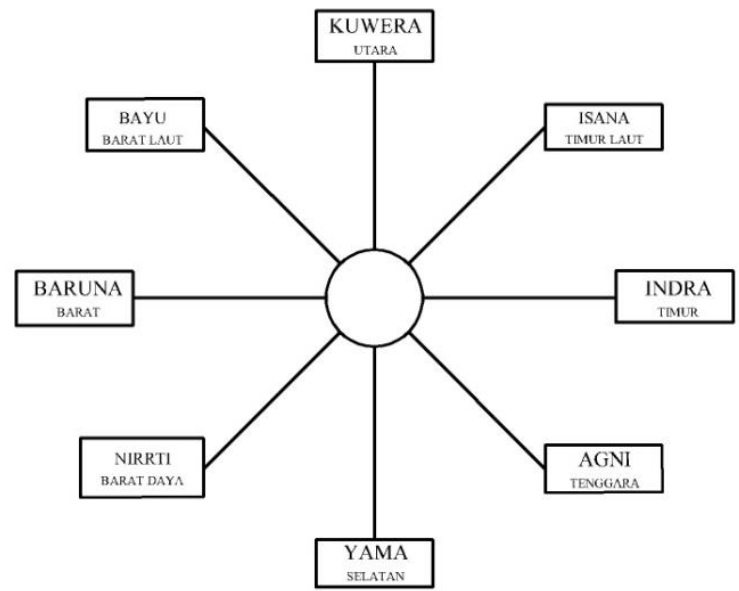

Gambar 2. Konsepsi Asta Dik Pala Sumber: Analisis, 2016

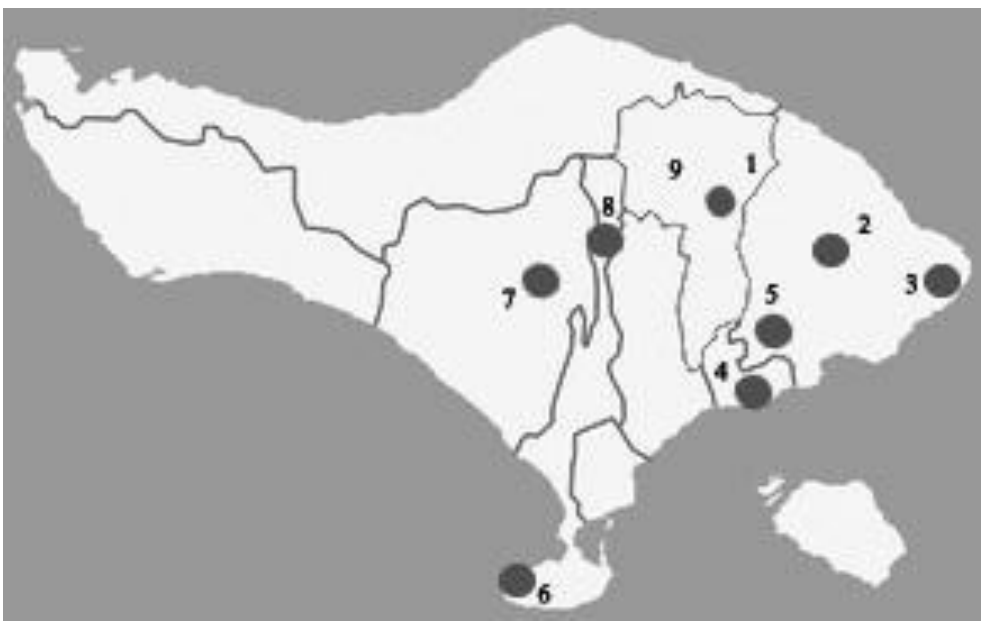

\begin{tabular}{|c|c|c|}
\hline \multicolumn{3}{|c|}{ Keterangan Gambar 3: } \\
\hline No. & Nama Pura & Nama Dewa \\
\hline 1. & Pura Batur & Dewa Wisnu \\
\hline 2. & Pura Besakih & Dewa Sambhu \\
\hline 3. & $\begin{array}{l}\text { Pura } \\
\text { Lempuyang }\end{array}$ & Dewa Iswara \\
\hline 4. & $\begin{array}{l}\text { Pura Goa } \\
\text { Lawah }\end{array}$ & $\begin{array}{l}\text { Dewa } \\
\text { Maheswara }\end{array}$ \\
\hline 5. & Pura Andakasa & Dewa Brahma \\
\hline 6. & Pura Uluwatu & Dewa Rudra \\
\hline 7. & Pura Batukaru & $\begin{array}{l}\text { Dewa } \\
\text { Mahadewa }\end{array}$ \\
\hline 8. & $\begin{array}{l}\text { Pura Pucak } \\
\text { Mangu }\end{array}$ & $\begin{array}{l}\text { Dewa } \\
\text { Sangkara }\end{array}$ \\
\hline 9. & Pura Besakih & Dewa Siwa \\
\hline
\end{tabular}

Gambar 3. Pura Padma Bhuwana/Pura Padma Astadala di Pulau Bali Sumber: Analisis, 2016

\section{Korelasi antara Konsepsi Padma dan Konsepsi Asta Dik Pala}

Konsepsi lain yang berkenaan dengan tokoh-tokoh dewa penjaga arah mata angin yang dikenal dalam ajaran Hindu Bali adalah Konsepi Asta Dik Pala. Konsepsi ini sangat populer di India, Napal, negara-negara di Semenanjung Asia Tenggara, dan negara-negara lain yang mendapat pengaruh budaya Hindu India. Di Pulau Jawa dan Pulau Bali, Konsepsi Asta Dik Pala tampaknya tidak sepopuler Konsepsi Dewata Nawa Sanga. Masyarakat Hindu kedua pulau bertetangga itu pada umumnya menganut Hindu sekte tertentu yang menempatkan Siwa sebagai dewa tertinggi. Dalam Konsepsi Dewata Nawa Sanga, tokoh Dewa Siwa memang dipuja sebagai dewa utama yang bersemayam di posisi tengah atau pusat.

Asta Dik Pala atau Așta Dik Pālaka secara harfiah berarti 'para penguasa delapan arah'. Para penjaga dalam konteks ini adalah mengacu pada delapan tokoh dewa Hindu yang terdiri dari Dewa Kuvera (Kuwera) sebagai penjaga arah utara, Dewa İsāna (Isana) sebagai penjaga arah timur laut, Dewa Indra sebagai penjaga arah timur, Dewa Agni sebagai penjaga arah tenggara, Dewa Yama sebagai penjaga arah selatan, Dewi Nirrti (Nirrti) sebagai penjaga arah barat daya, Dewa Varuna (Baruna) sebagai penjaga arah barat, dan Dewa Vāyu (Bayu) sebagai penjaga arah barat laut (lihat gambar 2). Kedelapan tokoh dewata juga digambarkan memiliki tugas, pasangan (sakti), dan senjata tersendiri. Selain delapan arah mata angin di 
atas, dikenal juga konsep dua arah lainnya, yaitu arah atas (zenith) dan arah bawah (nadir) yang masing-masing dijaga oleh Dewa Brahma dan Dewa Wisnu. Semua dewa penjaga ini mengitari sebuah titik kosong yang dimaknai sebagai titik pusat alam semesta yang sering kali digambarkan sebagai titik lokasi berdirinya sebentuk gunung mahasuci alam semesta yang bernama Meru (Thompson, 2007: 41).

Konsepsi Asta Dik Pala masih dapat dilihat secara jelas wujud penerapannya pada dinding luar bangunan Candi Siwa dalam kompleks bangunan Candi Prambanan, Jawa Tengah. Pada bagian pinggang candi ini dapat dijumpai adanya rangkaian pahatan relief tokoh-tokoh dewa Asta Dik Pala yang ditempatkan sesuai arah dan posisinya masing-masing.

Penerapan konsepsi delapan dewa penjaga arah mata angin ini juga diperkirakan diterapkan sebagai salah satu konsep penataan Kota Trowulan sebagai sebuah ibu kota Kerajaan Hindu Majapahit pada masa jayanya. Berbagai temuan arkeologis dan kondisi geografis sekitar situs menggiring keyakinan para arkeolog bahwa Trowulan merupakan sebuah kota kuno yang ditata dengan penerapan Konsepsi Asta Dik Pala yang diputar $90^{\circ}$ searah jarum jam (Munandar, 2008: 92-101). Keyakinan ini juga diperkuat dengan adanya lambang Kerajaan Majapahit yang bernama Surya Majapahit. Dalam lambang ini dapat dilihat adanya penggunaan simbol dewa-dewa Asta Dik Pala dan dewa-dewa dalam Dewata Nawa Sanga yang ditempatkan dalam simbol itu secara bersama-sama (lihat gambar 4).

Lebih jauh, diperkirakan sebagian Konsepsi Asta Dik Pala juga diterapkan sebagai konsep penataan area dan massa bangunan puri serta rumah tinggal masyarakat tradisional Bali yang berpola Sangamandala. Dalam konsep penataan puri - dan rumah tinggal - tersebut dapat djumpai bahwa area tempat suci dalam pekarangan pada umumnya berada pada sudut kaja-kangin atau sejalan dengan konsep penempatan Dewa Ísāna yang tidak lain adalah Dewa Siwa, sebagai dewa yang tertinggi dalam konstelasi dewa-dewa Asta Dik Pala (Munandar, 2005: 172).

\section{Korelasi antara Konsepsi Padma dan Kombinasi Konsepsi Dewata Nawa Sanga dan Konsepsi Asta Dik Pala}

Keberadaan konsepsi dewa-dewa penjaga arah mata angin - seperti Dewata Nawa Sanga dan Asta Dik Pala - dalam tatanan ritual dan pola penataan wilayah secara makro yang bercorak Hindu sangat berkaitan dengan cara pandang manusia terhadap wilayah huniannya pada masa lalu. Daerah hunian yang berupa suatu wilayah kerajaan maupun sebuah pulau, dalam pandangan yang berlatar konsepsi kosmologis Hinduistis lazimnya dimaknai sebagai suatu miniatur dan pusat alam semesta. Setiap kerajaan masa Hindu di Indonesia pada umumnya meyakini wilayahnya sebagai pusat alam semesta dengan puri atau istana dan sang raja penguasanya dipandang sebagai sebuah replika istana sorga dan seorang titisan dewa utama di dunia. Pandangan klasik semacam ini dikenal dalam pengetahuan sosiologi dan sejarah sebagai penerapan dari Konsepsi Dewa Raja (Heine-Geldern, 1956: 5$6)$.

Dalam pandangan berlatar Konsepsi Dewa Raja ini juga terdapat beberapa pemikiran khusus berkenaan wilayah suatu kerajaan. Wilayah kerajaan dimaknai sebagai wilayah yang harus aman terjaga secara sekala ('kasat mata') dan niskala ('tidak kasat mata'), pusat wilayah kerajaan dipandang sebagai miniatur pusat alam semesta yang dikelilingi oleh kekuatankekuatan suci para dewata di berbagai arah utama. Pemahaman semacam ini selanjutnya melahirkan gagasan penerapan konsepsi keberadaan dewa-dewa penjaga arah mata angin yang mengitari wilayah sebuah kerajaan maupun suatu wilayah pulau. Di Jawa dan di Bali, dua konsepsi tentang dewa-dewa penjaga arah mata angin yang paling populer dikenal dengan nama Konsepsi Dewata Nawa Sanga dan Konsepsi Asta Dik Pala.

Dalam perwujudan lambang Majapahit yang disebut oleh para sejarawan sebagai Surya Majapahit, kedua konsepsi dewa-dewa penjaga arah mata angin ini disatukan ke dalam 
bentuk satu diagram yang menyerupai ilustrasi matahari dan dua barisan garis pancaran sinarnya yang menyebar ke delapan arah yang berbeda. Konsepsi Dewata Nawa Sanga yang diperkirakan berasal dari pandangan lokal Nusantara itu disatukan dengan Konsepsi Asta Dik Pala yang lahir di tanah India Utara. Sembilan tokoh Dewata Nawa Sanga diposisikan di bagian dalam dengan tokoh Dewa Siwa berada di posisi paling tengah atau pusatnya, sedangkan delapan tokoh dewa Asta Dik Pala ditempatkan pada lapisan luar (Miksic, 1995: 124). Seluruh tokoh digambarkan tetap pada posisi arahnya masing-masing sesuai kedua konsepsi dasar tersebut. Kombinasi kedua konsepsi ini selain dalam diagram lebih terlihat sebagai cakram surya dengan dua lapisan jurai sinarnya, juga sejalan dengan gambaran bunga padma yang mengembang dengan sebuah sari di tengah-tengah dan dua lapisan kelopak bunga yang mengarah ke delapan arah yang berbeda (lihat gambar 5 dan 12).

Adanya konsep kombinasi antara dua konsepsi dari dua daerah asal berbeda ini dalam budaya Majapahit diperkirakan sangat berkaitan karakter budaya masa Majapahit yang disebut oleh para sejarawan sebagai tatanan budaya yang lahir dan mencapai masa kejayaannya dalam periode perkembangan budaya Hindu dan Buddha Nusantara (abad 11abad 15 Masehi). Masa ini digambarkan sebagai masa perkembangan budaya Hindu dan Buddha berkarakter asli Nusantara yang ditandai dengan berkurangnya eksistensi budaya Hindu dan Buddha dari India. Kenyataan yang berbeda dapat dicermati pada perwujudan Konsepsi Asta Dik Pala asli India pada pinggang bangunan Candi Siwa Prambanan. Candi besar yang dibangun pada masa perkembangan agama Hindu dan Buddha asli India di Nusantara (abad 8-abad 10 Masehi) ini memang belum menyertakan tatanan konseptual Dewata Nawa Sanga pada perwujudan bangunannya.

Konsepsi Asta Dik Pala juga semakin kurang populer dalam sistem kebudayaan dan arsitektur bangunan suci di Bali. Dalam tatanan konseptual Hindu Bali yang berkembang sejak dan sesudah masa Majapahit ini, kegiatan ritual dan tata ruang sucinya lebih cenderung hanya memuat Konsepsi Dewata Nawa Sanga. Bali yang merupakan wilayah bekas bawahan Kerajaan Majapahit memang lebih banyak mengembangkan budaya Hindu dan Buddha yang benar-benar telah diindonesiakan.

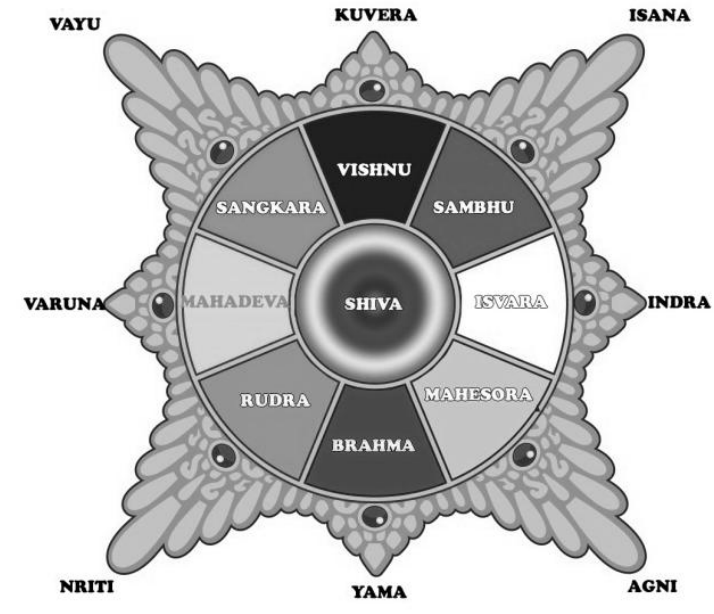

Gambar 4. Lambang Surya Majapahit Sumber: Analisis, 2016

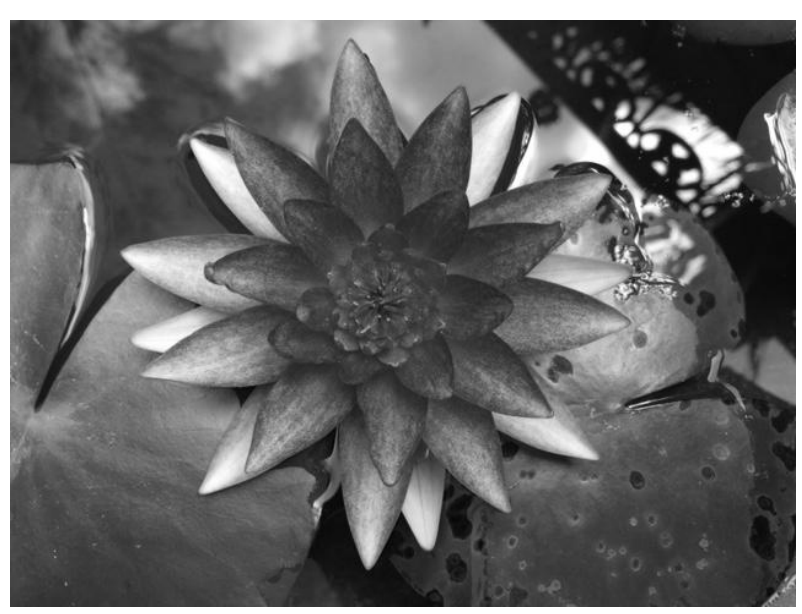

Gambar 5. Bunga Padma

Sumber: Survey, 2016

\section{Hasil dan Pembahasan}

Pada bagian berikut ini dipaparkan tentang gambaran hasil dan pembahasan dari penelitian yang telah dilakukan. 


\section{Keutamaan Padma}

Bunga indah dari spesies tanaman air yang tumbuh di lumpur ini, dalam ajaran Hindu dan Buddha dipandang sebagai bunga suci dengan banyak memuat nilai keutamaan yang tidak dimiliki oleh bunga tanaman lain pada umumnya. Padma selayaknya tanaman teratai pada umumnya, memiliki habitat hidup di tiga alam; yaitu darat (alam bawah), air (alam tengah), dan udara (alam atas). Akar teratai tumbuh menjalar dalam media tanah lumpur sebagai simbolisasi alam bawah; batang dan daunnya berada di air atau alam tengah; sedangkan bunganya mekar sempurna di udara sebagai perlambang eksistensi alam atas. Gambaran kehidupan tiga alam dari tanaman padma seperti di atas, dalam pemahaman Konsepsi Tri Loka dapat dimaknai pula sebagai tiga tingkatan alam semesta yang terdiri dari Bhur-Loka, Bvar-Loka, dan Svar-Loka. Lumpur dimaknai sebagai simbolisasi alam BhurLoka (alam manusia), air disetarakan dengan alam Bvar-Loka (alam peralihan), dan udara dipadankan dengan alam Svar-Loka (alam dewata) (Debroy dan Debroy, 2005: 768).

Sifat keutamaan lain yang dimiliki spesies tanaman teratai adalah berkenaan dengan karakter bunganya yang indah mampu mekar secara sempurna dan bersih tidak bernoda. Kenyataan seperti ini terkesan sangat kontradiktif dengan karakteristik media tumbuh tanaman teratai yang berupa tanah lumpur di dasar kolam air tawar. Bunga teratai yang mekar sempurna seolah-olah mampu memisahkan dirinya dari segala kekotoran yang ada di tempat hidupnya. Gambaran ini mengakibatkan bunga teratai dimaknai juga sebagai bunga suci dan agung. Dalam istilah Sanskertanya, segala jenis tanaman teratai disebut dengan nama Sarasija yang secara harfiah berarti 'lahir atau tumbuh di lumpur' (MacDonell, 1974: 340).

Karakteristik lain yang dimiliki bunga teratai adalah terletak pada perwujudan bunga teratai yang memiliki tiga bagian utama, yaitu sari bunga yang terdapat pada bagian tengahnya; jajaran kelopak bunga lapisan dalam yang bertekstur tipis halus; dan jajaran kelopak bunga lapisan luar yang bertekstur tebal dan lebih kasar (lihat gambar 5). Komposisi harmonis ketiga bagian bunga teratai semacam ini menyebabkan bunga tanaman air ini jika dilihat secara tegak lurus dari atas akan terlihat selayaknya bulatan matahari berwarna kuning cerah dengan dua lapisan jurai sinar matahari mengelilinginya. Gambaran fisik bunga teratai mekar yang seperti ini menjadikan teratai sebagai ilham lahirnya konsepsi tentang delapan arah utama mata angin yang disucikan di Bali, yaitu utara, timur laut, timur, tenggara, selatan, barat daya, barat, dan barat laut (Phalgunadi, 1991: 120). Kedelapan arah ini mengitari posisi pusat, selayaknya delapan kelopak utama bunga teratai yang mengitari sari utama bunga di pusatnya.

Dalam Konsepsi Pulau Padma Bhuwana ('Pulau Teratai Merah') dinyatakan bahwa Pulau Bali dinyatakan sebagai pulau suci yang dijaga oleh delapan dewa utama (Dewata Nawa Sanga) di delapan arah utama, selayaknya delapan kelopak bunga teratai itu. Kedelapan dewa dan satu dewa penjaga arah tengah itu selanjutnya diyakini bersemayam di sembilan posisi yang dinyatakan secara nyata dalam bentuk delapan kompleks bangunan pura yang utama yang dinamai Pura Kahyangan Jagat atau 'pura sorga di dunia' (Dwipayana dan Putra, 2004: 272) (lihat gambar 3).

Tanaman padma atau teratai merah adalah salah satu dari empat jenis tanaman teratai paling popular. Tiga jenis teratai lainnya adalah berwarna biru, kuning, dan putih. Keempat jenis teratai ini memiliki makna tersendiri dalam pandangan Hindu dan Buddha. Keempatnya juga memiliki nama tersendiri dan secara ikonografis diwujudkan dalam bentuk-bentuk tersendiri. Di antara keempat jenis bunga teratai ini, padma mendapat perhormatan sebagai bunga suci yang paling diutamakan.

\section{Warna Bunga Padma}

Bunga padma yang berwarna merah juga memuat nilai khusus yang selanjutnya dijadikan dasar pemilihan padma sebagai bunga suci dalam pandangan Hindu dan Buddha. 
Karakter bunga padma yang sedang mekar adalah merah merekah menengadah, lembut, dan mudah rapuh, sering kali juga dipasangkan dengan senjata Bajra (Vajra). Bajra adalah senjata Dewa Indra, dewa penguasa langit dan pengendali badai dan awan. Indra juga dikenal sebagai raja sorga yang dalam mitologi Hindu dan Buddha dikenal sebagai kerajaan para dewata yang disemayami 33 tokoh dewa utama. Bajra adalah senjata ampuh Indra yang digambarkan dapat menciptakan kilat di langit. Dalam beberapa konteks, Vajra juga diterjemahkan sebagai 'baja' dalam bahasa Sanskerta. Baja memang merupakan satu material logam dengan kekuatannya yang sangat solid.

Dalam kitab-kitab filosofi India, Bajra acap kali dipasangkan dengan bunga padma yang sedang mekar. Padma yang lembut dan sedang mekar merekah menengadah menjadi alas pijak bagi senjata Bajra dalam posisi berdiri. Bajra yang kaku, keras, dan tajam berdiri vertikal di atas alas berupa bunga padma yang lembut dan menengadah secara horizontal (lihat gambar 6). Pasangan Bajra-Padma dengan sifat masing-masing yang saling beroposisi ini sejalan dengan gambaran karakter pasangan Lingga-Yoni yang setara dengan konsepsi pasangan alam atas-alam bawah atau pasangan alam Tuhan-alam manusia. Kekuatan Tuhan di tingkatan alam atas yang kuat dan mampu menembus segala material sangat bertolak belakang dengan karakter manusia di dunia yang mudah terkoyak, rapuh, dan lemah. Umat manusia yang hidup di alam Mayapada sangat mudah terseret segala daya tarik dan ikatan duniawi.

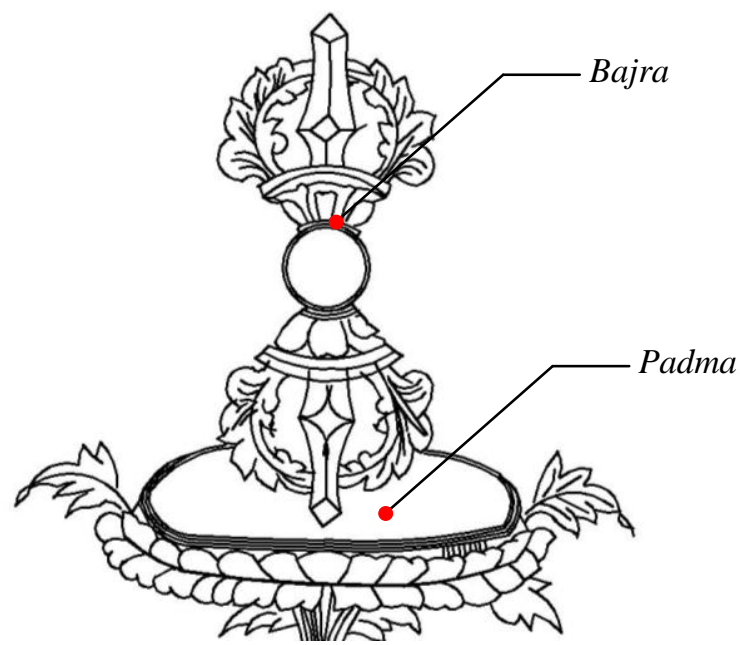

Gambar 6. Pasangan Bajra-Padma Sumber: Analisis, 2016

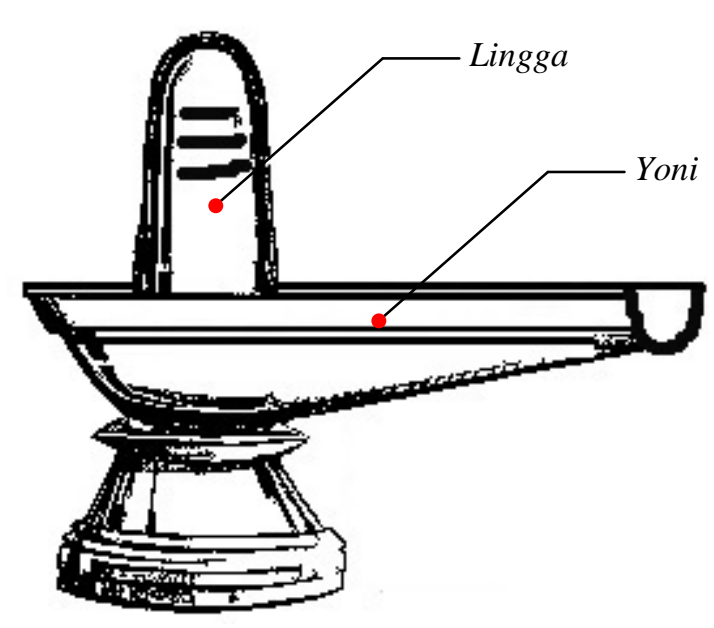

Gambar 7. Simbol Lingga-Yoni Sumber: Analisis, 2016

Pada bagian lainnya, pasangan Bajra-Padma juga dapat diartikan sebagai pasangan alat reproduksi laki-laki (penis) dan alat reproduksi perempuan (vagina). Hubungan harmonis antara penis dan vagina memang telah menjadi salah satu simbol utama hubungan harmonis hubungan Tuhan dan manusia (Lingga-Yoni) (Kapur, 1983: 65). Lingga sebagai simbol penis yang berwujud silinder vertikal berdiri di atas Yoni sebagai simbol vagina yang menengadah horizontal (lihat gambar 7). Pasangan Lingga-Yoni juga dimaknai sebagai pasangan alam atas (langit)-alam bawah (bumi) sebagai pasangan ayah-ibu bagi umat manusia. Langit sebagai pemberi energi (matahari) berpasangan dengan bumi sebagai tempat tumbuh dan hidup semua makhluk hidup (tanah). Berkenaan dengan pandangan konsepsual inilah selanjutnya lahir suatu pemikiran untuk menetapkan bunga teratai merah sebagai alas Bajra. Karakter dan warna merah bunga padma diidentikkan dengan karakter dan warna vagina, alat reproduksi perempuan yang lembut, merekah dan berwarna merah itu (Beer, 2003: 170). Pemikiran ini 
menjadikan dasar pemilihan bunga teratai merah sebagai pasangan Bajra, bukan bunga teratai putih, bunga teratai biru, maupun bunga teratai kuning.

\section{Perwujudan Bunga Padma dalam Seni Rupa Timur Klasik}

Padma atau teratai merah banyak ditemukan dalam karya seni rupa Timur klasik, baik yang berupa lukisan, relief, maupun arca. Dalam wujud lukisan maupun arca yang berwarna, padma sangat mudah dikenali berkat adanya teknik pewarnaan kelopak bunga merah cerah yang membedakannya dengan teratai berwarna biru, kuning, maupun putih. Tata cara penggambaran semacam ini banyak berlaku pada karya-karya seni rupa dari negara-negara di kawasan Asia Selatan, Asia Tenggara, dan Asia Timur. Padma dalam perwujudan seni rupa dengan teknik penyelesaian hitam putih atau pahatan tanpa penyelesaian warna, pada umumnya digambarkan sebagai sebentuk bunga teratai mengembang yang memiliki dua tipe barisan kelopak bunga sesuai arah mengembangnya. Satu tipe barisan kelopak mengembang ke arah atas dengan elemen sari bunga di tengahnya, sementara tipe barisan kelopak lainnya digambarkan mengembang dengan arah ke bawah (Scheurleer, dkk., 1988: 49). Adanya konsep ikonografis semacam ini menyebabkan sebuah pahatan padma yang tidak berwarna sekalipun menjadi tetap mudah dikenali dan dibedakan dengan pahatan bunga teratai dengan warna lainnya (lihat gambar 8, 9, dan 10).

Padma dalam seni rupa Timur klasik banyak dijadikan sebagai bentuk pijakan kaki atau alas duduk tokoh dewata. Dalam pengetahuan percandian Indonesia, pijakan kaki arca dewata yang banyak ditemukan sebagai artifak candi dikenal dengan sebutan lapik. Selain dari pada itu, pada beberapa arca atau lukisan tokoh dewa, padma juga diwujudkan sebagai atribut bunga genggam yang bermakna filosofis yang terkait dengan makna kesucian dan simbol jiwa yang mulia.

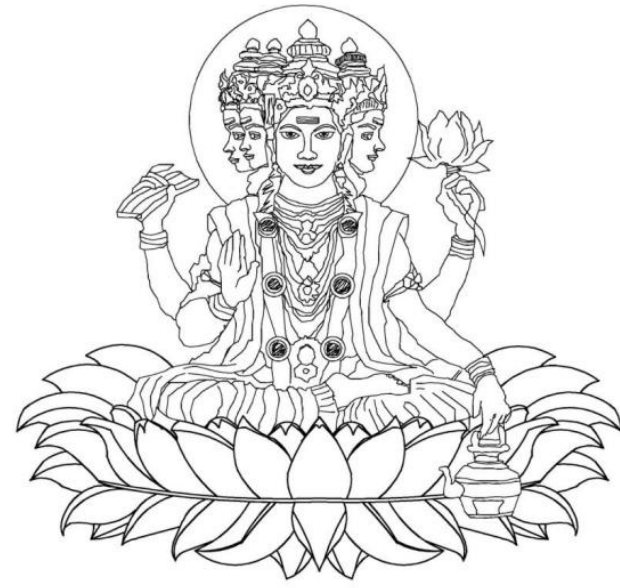

Gambar 8. Padma sebagai Lapik dan Atribut Dewa Brahma (India)

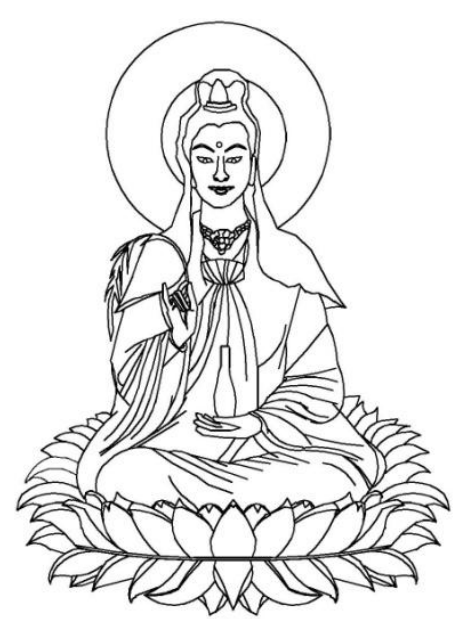

Gambar 9. Padma sebagai Lapik Dewi Kwan Im (Tiongkok)

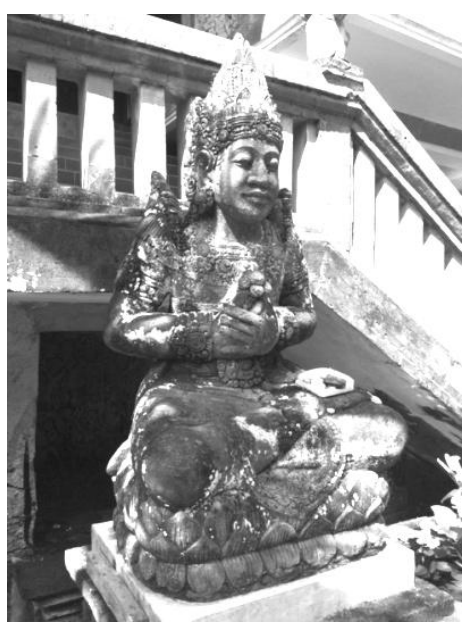

Gambar 10. Padma sebagai Lapik Arca di Bali

Sumber 8,9,10: Analisis, 2016; Survey, 2016

\section{Korelasi Padma dengan tata ruang: ruang inti dan ruang periferi, serta konsepsi matahari}

Wujud bunga padma yang mekar apabila dilihat dari atas akan terlihat sebagai adanya tiga area lapisan utama, yaitu elemen sari bunga sebagai elemen inti bunga; lapisan kelopak bunga bagian tengah; dan lapisan kelopak bunga bagian luar. Gambaran fisik bunga seperti ini menyebabkan bunga padma juga dapat diidentikkan dengan perwujudan matahari dengan lapisan-lapisan sinarnya dan lapisan telur yang tersusun dari adanya elemen kuning telur 
(elemen inti yang paling utama), putih telur (elemen peralihan), dan kulit telur (elemen terluar). Adanya gambaran relasi kesetaraan makna yang terbentuk antara wujud bunga padma yang sedang mekar, matahari, dan telur juga telah menjadi dasar lahirnya berbagai perwujudan tata ruang tradisional Bali secara horizontal yang tersusun atas adanya area inti yang paling disakralkan (utama); area periferi atau area peralihan yang bernilai menengah (madya); dan area luar yang bernilai paling profan (nista). Konsepsi yang mengetengahkan tentang tiga tipe area berdasarkan tingkatan kesuciannya ini di Bali dikenal dengan sebutan Konsepsi Tri Mandala.

\section{Konsepsi Padma dalam Tata Ruang di Bali: Konsepsi Arah Mata Angin, Seni Arsitektur, dan Seni Rupa \\ Pada bagian berikut ini dipaparkan tentang wujud penerapan Konsepsi Padma dalam} tata ruang, seni arsitektur, dan seni rupa tradisional Bali.

\section{a. Padma dalam Konsepsi Empat Warna dan Empat Arah Mata Angin Utama}

Bunga teratai merah bersama dengan tiga teratai lainnya telah menjadi ilham lahirnya konsepsi empat warna utama dalam pandangan Hindu dan Buddha, yaitu warna merah, biru, kuning, dan putih. Konsepsi empat warna utama ini selanjutnya jika dipadankan dengan konsepsi empat arah mata angin utama yang dikenal dalam pandangan Kosmogonis Hindu dan Buddha - arah utara, timur, selatan, dan barat - juga telah melahirkan suatu ketetapan di Bali bahwa (a) warna merah ( padma) berada di selatan sebagai simbolisasi Dewa Brahma; (b) warna biru (utpala) atau hitam berada di utara sebagai simbolisasi Dewa Wisnu; (c) warna kuning (nilpala) berada di barat sebagai simbol Dewa Mahadewa; dan (d) warna putih (kumuda) berada di timur sebagai simbol Dewa Iswara. Konsepsi ini selanjutnya ditafsirkan telah berkembang menjadi acuan dasar dari keberadaan Konsepsi Dewata Nawa Sanga dan Konsepsi Kahyangan Jagat di Bali.

\section{b. Elemen Bunga Padma di Puncak Padmasana}

Dalam pengetahuan seni bangunan suci Hindu di Bali dikenal adanya dua tipe bangunan suci utama yang difungsikan sebagai bangunan suci pemujaan kepada Tuhan Yang Mahaesa. Bangunan suci tersebut bernama Padmasana dan Padmasari. Sesuai dengan namanya, kedua jenis bangunan ini mengambil bentuk dasar yang bertalian dengan konsepsi bunga padma.

Kedua bentuk bangunan suci ini mudah dikenali berkat adanya elemen ciri khasnya yang berwujud sebentuk kursi singgasana di atas puncak bangunan suci ini. Pada bagian sandaran punggung kursi singgasana ini lazimnya dipahatkan relief Acintya sebagai simbol Tuhan Yang Mahaesa dalam ajaran Hindu Bali. Tuhan dalam konteks ini digambarkan sebagai maharaja alam semesta yang duduk di atas kursi singgasana di atas bunga padma yang sedang mekar di puncak bangunan suci utama ini (lihat gambar 11).

Wujud bunga padma yang sedang mekar yang berada di puncak bangunan Padmasana dan Padmasari ada kalanya juga sudah dimodifikasi sedemikian rupa sesuai kreativitas seniman pemahatnya. Akibatnya, eksistensi elemen bunga padma pada kedua jenis bangunan suci ini menjadi kurang terlihat dalam pandangan masyarakat umum. 

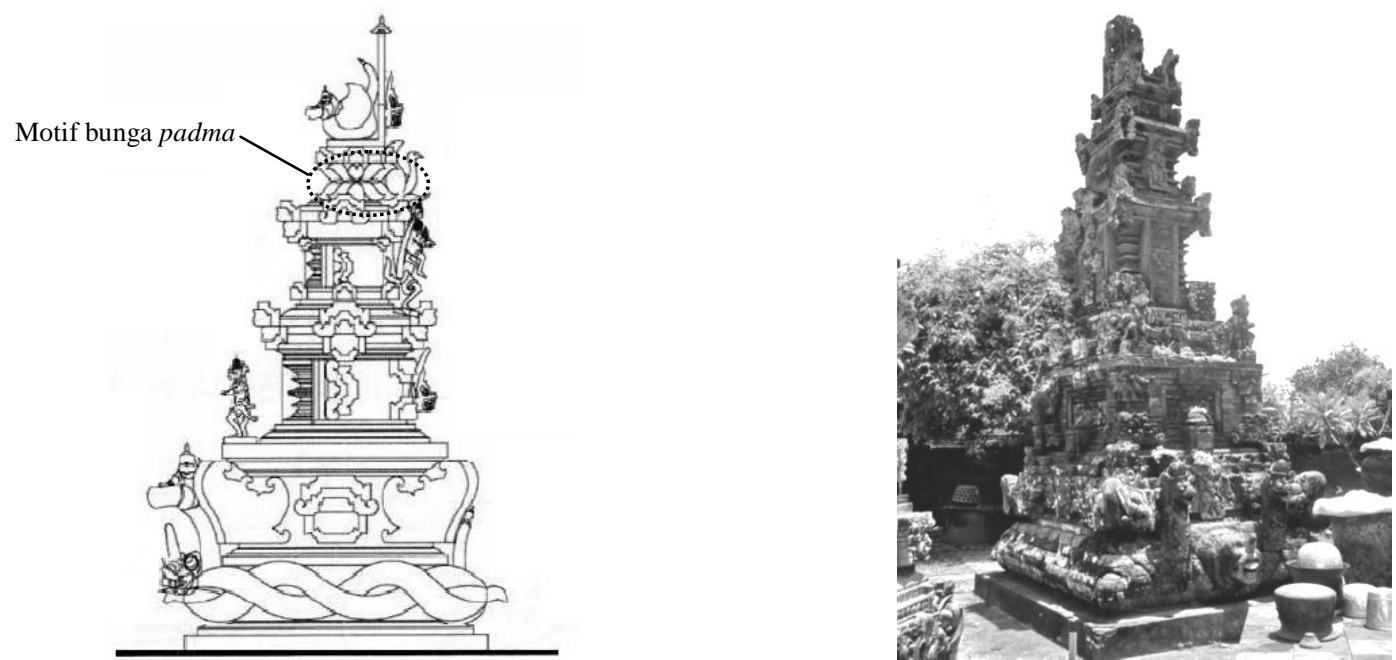

Gambar 11. Bangunan Suci Padmasana

Sumber: Analisis, 2016; Survey, 2013

\section{c. Elemen Sari Bunga Padma sebagai Inti Ruang}

Wujud bunga padma yang secara horizontal terlihat tersusun dari adanya (1) elemen sari di tengah bunga; (2) lapisan kelopak bunga bagian tengah; dan (3) lapisan kelopak bunga bagian luar menjadi ilham wujud tata ruang dan tata denah bangunan tradisional Bali sebagai berikut.

\section{Tata ruang Pulau Bali}

Keberadaan elemen sari bunga padma dalam tata ruang Pulau Bali teraplikasikan sebagai titik pusat Pulau Bali itu sendiri yang secara ritual dan kultural ditempatkan berada di Gunung Agung. Di wilayah gunung tertinggi di Pulau Bali ini tersebar banyak kompleks pura dengan sebuah pura utama yang bernama Pura Penataran Agung Besakih. Seperti telah diketahui, Pura Penataran Agung Besakih atau yang lebih dikenal sebagai Pura Besakih ini memang merupakan sebuah kompleks pura besar yang menjadi induk semua pura yang ada di seluruh Bali. Pura Besakih adalah tempat pemujaan Dewa Siwa, dewa tertinggi dalam konsepsi Hindu Bali yang dalam Konsepsi Dewata Nawa Sanga ditempatkan di posisi pusat. Selain dari pada itu, Pura Besakih ini juga menjadi tempat pemujaan dewa-dewa Tri Murti (Tiga Dewa Utama Hindu Bali) dan Dewa Sambu sebagai satu inkarnasi lain dari Dewa Siwa.

Elemen sari bunga padma yang diwujudkan sebagai Pura Besakih ini selanjutnya dikitari oleh sejumlah pura lain yang berstatus lebih rendah. Kompleks-kompleks pura ini berfungsi sebagai tempat pemujaan dewa-dewa penjaga arah mata angin yang dapat disepadankan sebagai delapan helai kelopak bunga padma itu sendiri. Pura Besakih dan sejumlah pura utama pengelilingnya ini selanjutnya dikenal dengan sebutan Pura Kahyangan Jagat daerah Bali (lihat gambar 3).

\section{Konsepsi Tri Mandala Pura}

Eksistensi elemen sari dan dua lapis kelopak bunga padma ini juga memiliki kesesuaian dengan Konsepsi Tri Mandala Pura. Area kompleks pura di Bali lazimnya tersusun atas tiga area utama, yaitu (a) area utama mandala atau jeroan sebagai area inti pura; (b) area madya mandala atau jaba tengah sebagai area transisi pura; dan (c) area nista mandala atau jaba sisi sebagai area terluar pura. Konsepsi pembagian tiga area mandala pura ini sangat sejalan dengan konsep pembagian tiga yang termuat dalam wujud fisik bunga padma yang sedang mekar, yaitu (a) elemen sari sebagai elemen atau ruang inti bunga; (b) barisan kelopak bunga 
bagian dalam sebagai area periferi bunga padma; dan (c) barisan kelopak bunga bagian luar sebagai area luar bunga padma (lihat gambar 12 dan 13).

Dalam perwujudannya, Konsepsi Tri Mandala pada kompleks pura di Bali tidak diwujudkan dengan pola memusat. Hal ini didasarkan pada telah adanya perkawinan dengan konsep lain yang berkenaan dengan konsep arah sakral-profan secara horizontal dalam kosmologi Hindu Bali. Area utama mandala atau jeroan pura di Bali pada umumnya akan di posisikan pada zona yang berorientasi ke lokasi gunung utama atau ke arah matahari terbit (timur). Arah posisi gunung dan utara merupakan arah yang dimaknai sebagai dua arah yang bernilai utama atau sakral. Adapun arah-arah oposisinya, yaitu arah laut dan arah matahari terbenam (barat) merupakan dua arah yang bernilai nista atau paling profan. Kedua arah ini menjadi dasar penetapan zona nista mandala (jaba sisi) dalam area pura.

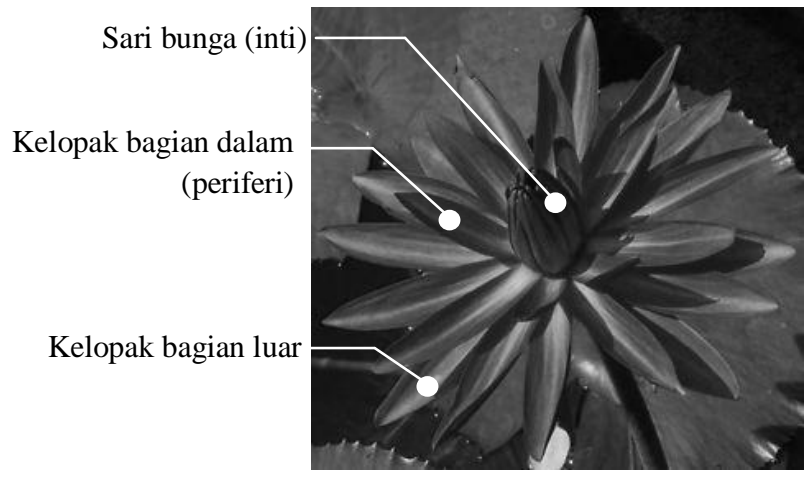

Gambar 12. Tiga Elemen Inti Bunga Padma Sumber: Analisis, 2016

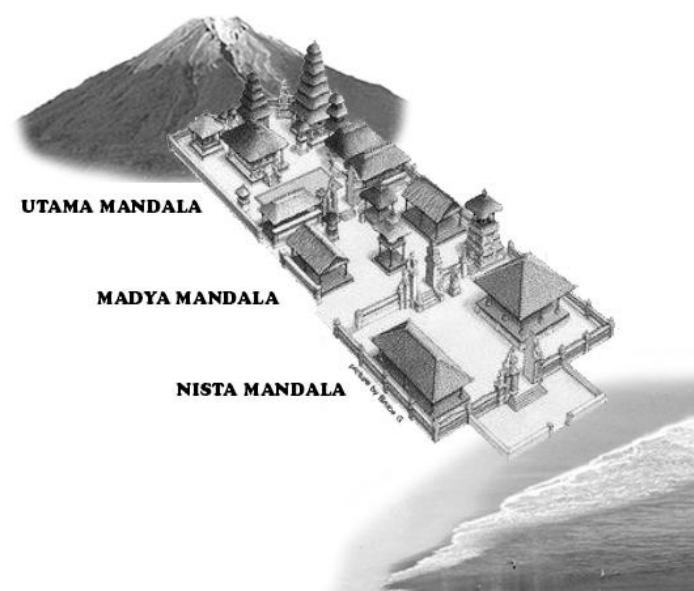

Gambar 13. Tri Mandala Pura

Sumber: Analisis, 2016

\section{d. Padma dalam Perwujudan Ikonografis Arca dan Ornamen Bangunan Tradisional Bali}

Padma dalam seni arca tradisional Bali lazimnya dirupakan dalam wujud sebagai bunga teratai yang mekar menengadah sempurna ke atas selayaknya seni rupa klasik Timur. Padma mudah dikenali dari ciri khasnya secara ikonografis, yaitu memiliki dua lapisan kelopak bunga yang masing-masing menghadap ke atas dan ke bawah. Selayaknya bunga yang disucikan, bunga padma juga dijadikan alas duduk atau berdiri arca tokoh dewata yang lazim terdapat dalam kompleks bangunan pura di Bali (lihat gambar 10 dan 14).

Dalam seni ragam hias bangunan, juga dikenal ada banyak jenis ornamen yang menerapkan padma sebagai motif dasar perwujudannya. Dalam seni ragam hias bangunan Bali, tanaman padma dirupakan secara lebih lengkap, mulai dari batang, daun, kuncup bunga, hingga bunganya yang sedang mekar sempurna. Ragam hias yang mengambil motif tanaman padma yang merambat antara lain Patra Sari, Patra Cina, Patra Samblung, dan Patra Punggel (lihat gambar 15-16). Ragam hias semacam ini lazimnya ditemukan mengisi dinding-dinding bangunan tradisional Bali dari material batu alam, bata merah, maupun kayu. 

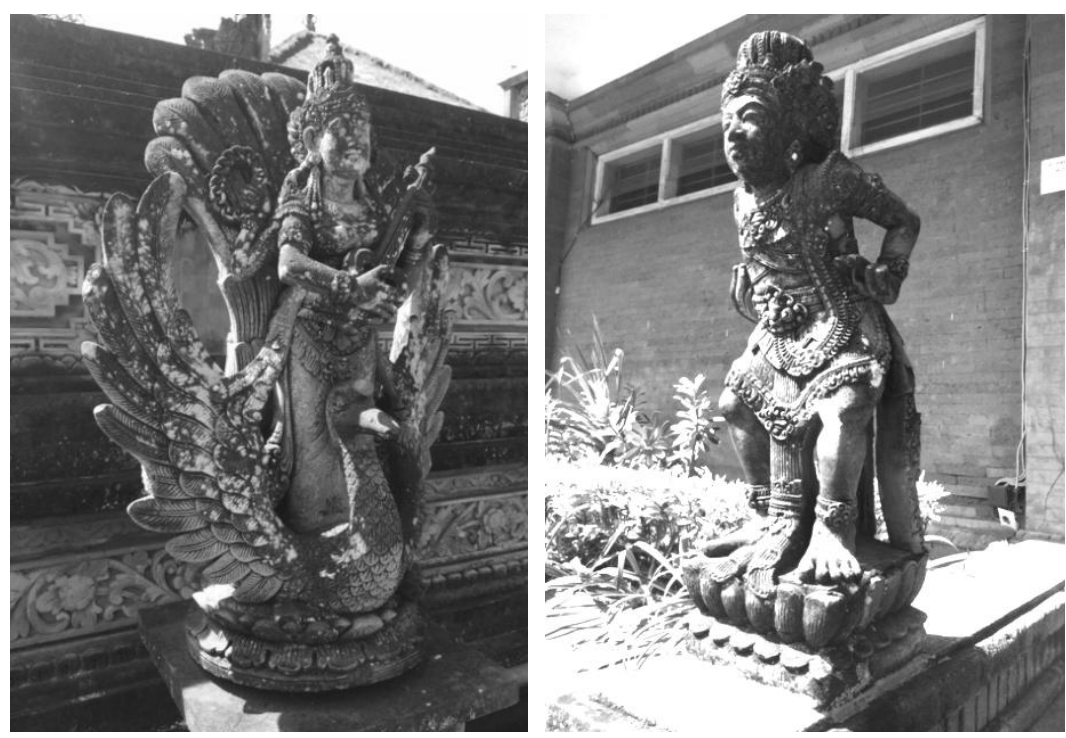

Gambar 14. Bunga Padma sebagai Lapik Arca Dewata

Sumber 14,15: Survey, 2016

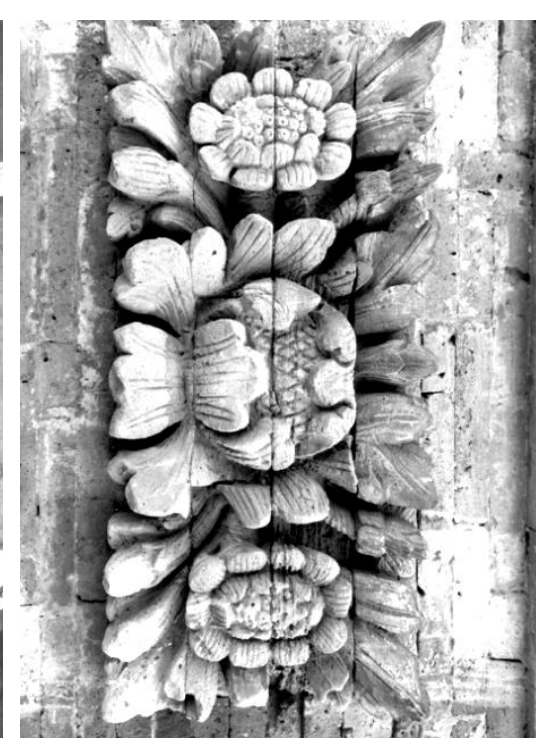

Gambar 15. Ornamen Bunga Padma

Sumber 1
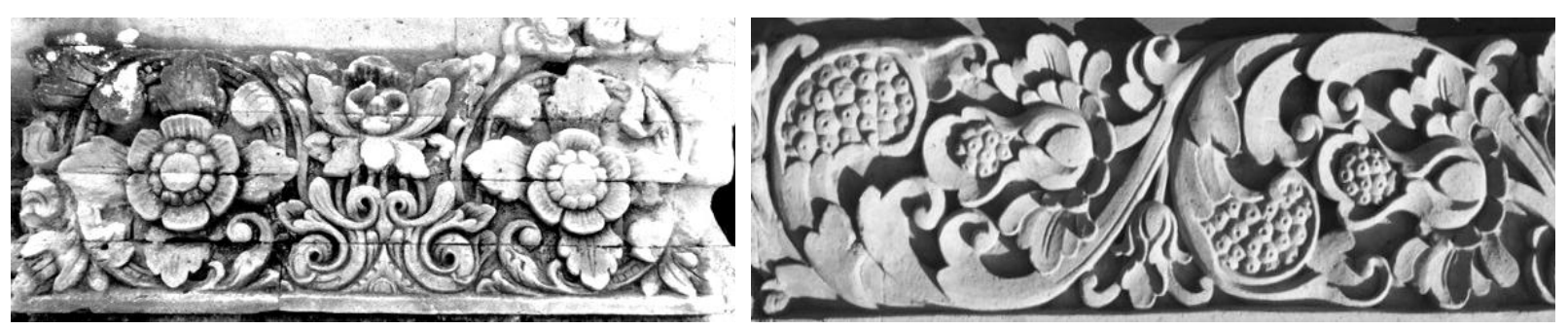

Gambar 16. Ornamen Bunga Padma yang Lengkap

Sumber: Survey, 2016

\section{Kesimpulan}

Padma adalah satu jenis bunga teratai yang telah dimaknai sebagai bunga suci dalam ajaran Hindu dan Buddha. Penetapan padma sebagai bunga suci ini didasarkan dari karakter tanaman dan bunga padma yang sedemikian rupa yang menunjukkan sifat-sifat keutamaan dan kesucian.

Sejalan dengan sifat keutamaan yang dimilikinya itu, padma juga telah banyak menjadi ilham lahirnya konsepsi utama dan motif-motif karya seni rupa yang terkait dengan tata ruang, arsitektur, dan arca yang bernilai keagamaan di Bali. Wujud-wujud penerapan konsepsi dan motif padma tersebut dapat dipaparkan sebagai berikut.

1. Dalam konsepsi tata ruang Pulau Bali terejawantahkan sebagai keberadaan Pura Kahyangan Jagat Pulau Bali yang disebut juga sebagai Pura Padma Astadala ('pura delapan kelopak bunga padma').

2. Dalam tata ruang denah pura disimbolisasikan sebagai tiga mandala pura, yaitu jeroan, jaba tengah, dan jaba sisi pura yang masing-masing memiliki tingkat kesucian tertentu.

3. Dalam seni arsitektur bangunan suci diwujudkan salah satunya dengan keberadaan bangunan suci utama umat Hindu Bali, seperti sebagai bangunan Padmasana dan Padmasari.

4. Dalam seni arca dan ragam hias bangunan, dirupakan dalam wujud lapik arca, atribut tokoh dewata, dan sebagai motif berbagai wujud ragam hias. 


\section{Daftar Pustaka}

Altman, Nathaniel (2002). Sacred Water: The Spiritual Source of Life. New Jersey: Paulist Press.

Beer, Robert (2003). The Handbook of Tibetan Buddhist Symbols. Chicago: Serindia Publications, Inc.

Debroy, Bibek dan Dipavali Debroy (2005). The History of Puranas. New Delhi: Bharatiya Kala Prakashan.

Dwipayana, A. A. G. N. Ari dan Putra, I Nyoman Darma (2004). Bali Menuju Jagaditha: aneka perspektif. Denpasar: Pustaka Bali Post.

Eiseman, Fred B. dan Margaret H. Eiseman (1989). Bali, Sekala and Niskala: Essays on religion, ritual, and art. Volume 1. London: Periplus Editions.

Gupte, Ramesh Shankar (1980). Iconography of the Hindus, Buddhists, and Jains. Delhi: D. B. Taraporevala Sons.

Heine-Geldern, Robert (1956). Conceptions of State and Kingship in Southeast Asia. New York: SEAP Publications.

Kapur, Sohaila (1983). Witchcraft in Western India. New Delhi: Orient Longman.

MacDonell, Arthur Anthony (1974). A Prctical Sanskrit Dictionary: with transliteration, accentuation, and etymological analysis throughout. London: Oxford University Press.

Manuaba, Adnyana dan Supartha, Wayan (1999). Bali dan Masa Depannya. Denpasar: Penerbit Bali Post.

Miksic, John N (1995). The Legacy of Majapahit. Singapore: National Heritage Board.

Munandar, Agus Aris (2005). Istana Dewa Pulau Dewata: Makna Puri Bali Abad ke-14-19. Depok: Komunitas Bambu.

Munandar, Agus Aris (2008). Ibukota Majapahit: Masa Jaya dan Pencapaian. Depok: Komunitas Bambu.

Phalgunadi, I Gusti Putu (1991). Evolution of Hindu Culture in Bali: From the Earliest Period to the Present Time. Delhi: Sundeep Prakashan.

Scheurleer, Pauline C. M. Lunsingh, dkk. (1988). Ancient Indonesian Bronzes: A Catalogue of the Exhibition in the Rijksmuseum Amsterdam with a General Introduction. Leiden: Brill Archive.

Thompson, Richard L (2007). The Cosmology of the Bhagavata Purana: Mysteries of the Sacred Universe. Delhi: Motilal Banarsidass Publisher.

Wiana, Ketut (2004). Mengapa Bali disebut Bali. Denpasar: Paramita. 